\title{
The influence of carbon nanotubes on the sensitivity of humidity sensors based on organic-inorganic polymer materials
}

\author{
E.A.Lysenkov ${ }^{1}$, O.V.Stryutskiy ${ }^{2}$, Yu.P.Gomza ${ }^{2}$, V.V.Klepko ${ }^{2}$ \\ ${ }^{1}$ Mykolayiv National University V.O.Sukhomlynskiy, \\ 24 Nikolska Str., 54030 Mykolayiv, Ukraine \\ ${ }^{2}$ Institute of Macromolecular Chemistry, National Academy of Sciences of \\ Ukraine, 48 Kharkivske Shosse, 02160 Kyiv, Ukraine
}

\section{Received October 20, 2014}

\begin{abstract}
The method of sol-gel synthesis of ion-conducting organic-inorganic polymeric nanocomposites modified with carbon nanotubes in amount of 0.1-1.0 wt. \%. was developed. The obtained materials were used for fabrication of humidity sensors which were investigated for their sensor properties. It was established that sensor characteristics of the developed materials are significantly dependent on carbon nanotubes content that caused by percolation processes. The optimum characteristics were shown by the material based on organic-inorganic matrix filled with $0.1 \%$ carbon nanotubes.

Keywords: organic-inorganic polymeric nanocomposites, carbon nanotubes, sol-gel synthesis, humidity sensors.
\end{abstract}

\footnotetext{
Разработан метод золь-гель синтеза ион-проводящих органо-неорганических полимерных нанокомпозитов, модифицированных углеродными нанотрубками в количестве 0.1-1 \%. Полученные материалы использовались для изготовления датчиков влажности, сенсорные свойства которых также исследованы. Установлено, что сенсорные характеристики разработанных материалов значительно зависят от содержания углеродных нанотрубок, что вызвано процессами перколяции. Наиболее оптимальные характеристики из всех исследованных параметров показал сенсорный материал, основанный на органо-неорганической матрице, наполненной $0.1 \%$ углеродных нанотрубок.
}

Вплив вуглецевих нанотрубок на чутливість сенсорів вологості на основі органонеорганічних полімерних матеріалів. Е.А.Лисенков, О.В.Стрюцький, Ю.П.Голза, В.В.Клепко.

Розроблено метод зол-гель синтезу іон-провідних органо-неорганічних полімерних нанокомпозитів, модифікованих вуглецевими нанотрубками у кількості 0,1-1 \%. Отримані матеріали використано для виготовлення датчиків вологості, сенсорні властивості яких також досліджено. Встановлено, що сенсорні характеристики розроблених матеріалів значно залежать від вмісту вуглецевих нанотрубок, що викликано процесами перколяції. Найбільш оптимальні характеристики із досліджених параметрів показав сенсорний матеріал, оснований на органо-неорганічній матриці, наповненій $0,1 \%$ вуглецевих нанотрубок.

\section{Introduction}

The level of relative humidity $(R H)$ is one of the major characteristics of any microclimate-related development objects (do- mestic and production apartments, vacuum chambers, pharmaceutical compositions, medical establishments and others). Therefore, creation of new sensors and improvement of their measuring characteristics in- 
tended for determination and control of humidity in gas environments is an important direction of scientific reseatch [1].

A whole set of important requirements such as high sensitivity and selectivity, fast response time and recovery time, low analyst consumption, independence or low dependence on temperature, stability in performances [1] is put to the sensors that must provide high-quality control of humidity in gas environments. In general, there requirements are satisfied in sensors created on the basis of polymeric materials.

The polymeric composite materials filled with carbon nanotubes (CNT) attract great attention [2]. These materials demonstrate excellent physical properties and functional characteristics. In particular, introduction of a very small quantity of CNT in a polymeric material may significantly affect its electrical conductivity [3], mechanical properties [4], thermal stability [5], etc. The main obstacle to good functionality of such materials is connected with poor dispersibility of CNT in most of liquid mediums (solvents, polymers, liquid crystals) and low stability of their dispersions caused by strong van der Waals attraction between different CNT [6, 7]. This obstacle can be avoided by functionalization of CNT, introduction of surface active chemical additives [8] or other nanoparticles [9] and using organic-inorganic polymeric materials as matrix [10].

Capacitive-resistive polymeric composite sensors of humidity have been widely investigated by the different groups of authors [11-13]. For instance, Tang et al. [11] developed film composite humidity sensors based on polyimide and CNT, which were characterized by fast response and recovery on changing of environment humidity. Li et al. [12] investigated the properties of sensors based on poly(4-vinypyridine) and carbon black in the wide range of humidity and noted for the developed sensors low time of recovery during the fall-off of humidity. Yu et al. [13] developed and investigated the sensitive characteristics of humidity sensors based on polyethyleneimine and CNT. All above mentioned sensors were characterized by a linear recovery in the wide range of humidity.

One of the most promising materials for sensor technologies are hybrid organic-inorganic materials synthesized by the sol-gel method. Wide possibilities of varying their physical, chemical and different functional properties are thus provided by changes in the synthesis conditions [14].

Sensors based on ion-conducting organicinorganic materials are widely utilized in world practice for detection of aromatic compounds [15], oxygen [16], carbon dioxide [17] and humidity level [18]. Previous investigations were concentrated on the possibilities of modifications of ion-conducting organic-inorganic sol-gel materials based on silicon-phosphate inorganic components which possessed high conductivity levels [19] for their adaptation to the conditions of performance of capacitive-resistive and electrochemical gas sensors. It was established that the feature of silicon-phosphate materials is the presence of silicate inorganic network which contains the system of micropores and mesopores filled with proton-conducting electrolyte, in particular, phosphoric acid [20]. The levels of proton conductivity of such material essentially depend on sizes and features of spatial organization of the micropores, and these materials are not stable because of the presence of phosphoric acid. Successful functioning of such proton-conducting films as sensory environments needs the combination of a few contradictory characteristics, such as high levels of conductivity, mechanical strength and long-term stability, especially during work in the conditions of high temperature and high humidity.

For creation of humidity sensors, which would satisfy the foregoing conditions, the hybrid sensory materials of our development obtained via incorporation of CNT into the ion-conducting organic-inorganic nanocomposite sol-gel matrix based on polyethylene oxide have been used in this study. The modification of the hybrid matrix polymer with CNT was carried out with a purpose to increase the level of ionic conductivity, linearity and speed of recovery of the sensors based on them [11]. The effects of CNT on sensitive properties of the developed materials as a part of humidity sensors was investigated.

\section{Experimental}

Organic-inorganic ion-conducting polyethylene oxide matrix modified with CNT during sol-gel synthesis was utilized for research of conductivity of nanocomposite sensory materials.

The initial for sol-gel process $\alpha, \omega$-dialkoxysilyl polyethyleneoxide urethaneurea precursor PEG-Si based on PEG $M_{n}=1000$ and alkoxysilyl lithiumsulfonate urea pre- 


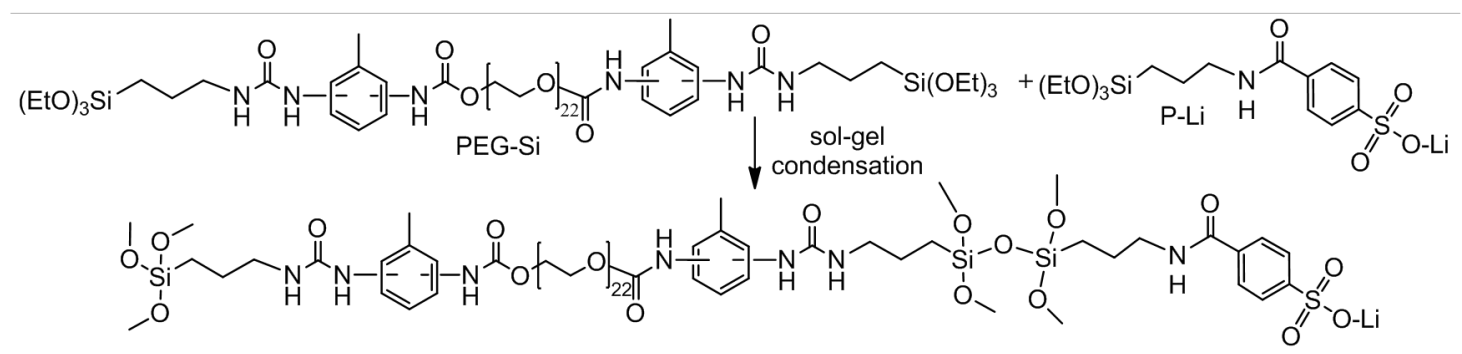

Fig. 1. The scheme of synthesis of matrix ion-conducting organic-inorganic nanocomposite.

cursor $\mathrm{P}-\mathrm{Li}$ were synthesized according to the procedure as described earlier [21]. The investigated organic-inorganic nanocomposite matrix was obtained via joint hydrolytic condensation of PEG-Si and P-Li at a weight ratio of $60: 40$, respectively, under acidic catalysis $(0.1 \mathrm{~N} \mathrm{HCl})$ in $30 \%$ solution in DMFA according to [21].

The multi-walled carbon nanotubes were prepared from ethylene using the chemical vapor deposition (CVD) method (TM Spetsmash Ltd., Kyiv, Ukraine) with FeAlMo as a catalyst [22]. They were further treated by alkaline and acidic solutions and washed by distilled water until reaching the distilled water $\mathrm{pH}$ values in the filtrate. The typical outer diameter $d$ of CNT was $20-40 \mathrm{~nm}$, their length $L$ ranged from 5 to $10 \mu \mathrm{m}$, and the mean aspect ratio was $a=L / d \approx 250$.

The specific surface area $S$ of the powders determined by $N_{2}$ adsorption was $S=130 \pm 5 \mathrm{~m}^{2} / \mathrm{g}$. The specific electric conductivity $\sigma$ of the powder of CNT compressed at $15 \mathrm{TPa}$ was about $10 \mathrm{~S} / \mathrm{cm}$ along the axis of compression. The density of the CNT was assumed to be the same as the density of pure graphite, $\rho_{n}=2045 \mathrm{~kg} / \mathrm{m}^{3}$.

The composites were obtained by adding the appropriate weights of CNT to the polymer matrix with subsequent 5 min sonication of the mixture using a UZDN-2T ultrasonic disperser at frequency of $22 \mathrm{kHz}$ and the output power of $150 \mathrm{~W}$. The series of samples with content of CNT within 0.11 wt. \% (in further \%) were investigated.

The experimental samples of sensors were fabricated as follows. The mixture of precursors PEG-Si and P-Li in DMFA containing required amount of CNT and catalyst was applied to lining with interdigital electrodes and aged for $24 \mathrm{~h}$ at room temperature with further thermal treatment during $4 \mathrm{~h}$ at $60^{\circ} \mathrm{C}, 2 \mathrm{~h}$ at $80^{\circ} \mathrm{C}, 1 \mathrm{~h}$ at $100^{\circ} \mathrm{C}$ and $1 \mathrm{~h}$ at $120^{\circ} \mathrm{C}$.
For research of the sensory characteristics in the controlled atmosphere, the developed sensors were placed above the surface of supersaturated salts solutions which supported the set levels of $R H$ in a range from $0 \%$ to $96.5 \%$ at the set temperatures. The dependences of $a c$-electrical conductivity $\sigma$ on $R H$ and temperature were estimated by the method of impedance spectroscopy using a instrument Z-2000 instrument in the frequency range $100 \mathrm{~Hz}-$ $100 \mathrm{kHz}$. The real $\left(Z^{\prime}\right)$ and imaginary $\left(Z^{\prime \prime}\right)$ parts of the sample impedance were measured using plate geometry cell with steel electrodes. Following the technique described in [23], the $a c$ conductivity was determined from the complex impedance dependence using the formula

$$
\sigma_{a c}=\frac{d}{S Z^{\prime}}
$$

where $S$ is the specimen area, and $d$ is its thickness.

\section{Results and discussion}

The matrix ion-conducting organic-inorganic nanocomposite developed in this work (Fig. 1) is characterized by the presence of lithium sulphonate groups in its composition, which is the source of lithium ions for realization of ionic transfer process, and polyethylene oxide component $\left(M_{n} 1000\right)$, which performs the role of ion-conducting environment and provides flexibility of the material [21].

In the process of sol-gel synthesis of this matrix the nanosize silsesquioxane areas, which provide suppressing of possible crystallization of foregoing ethyleneoxide fragments [24] and an increase in the mechanical strength and thermal stability of the material, are being formed in this composition [25]. Thus the amorphisation of the polyethyleneoxide part leads to growth of its ionic conductivity level [24]. 

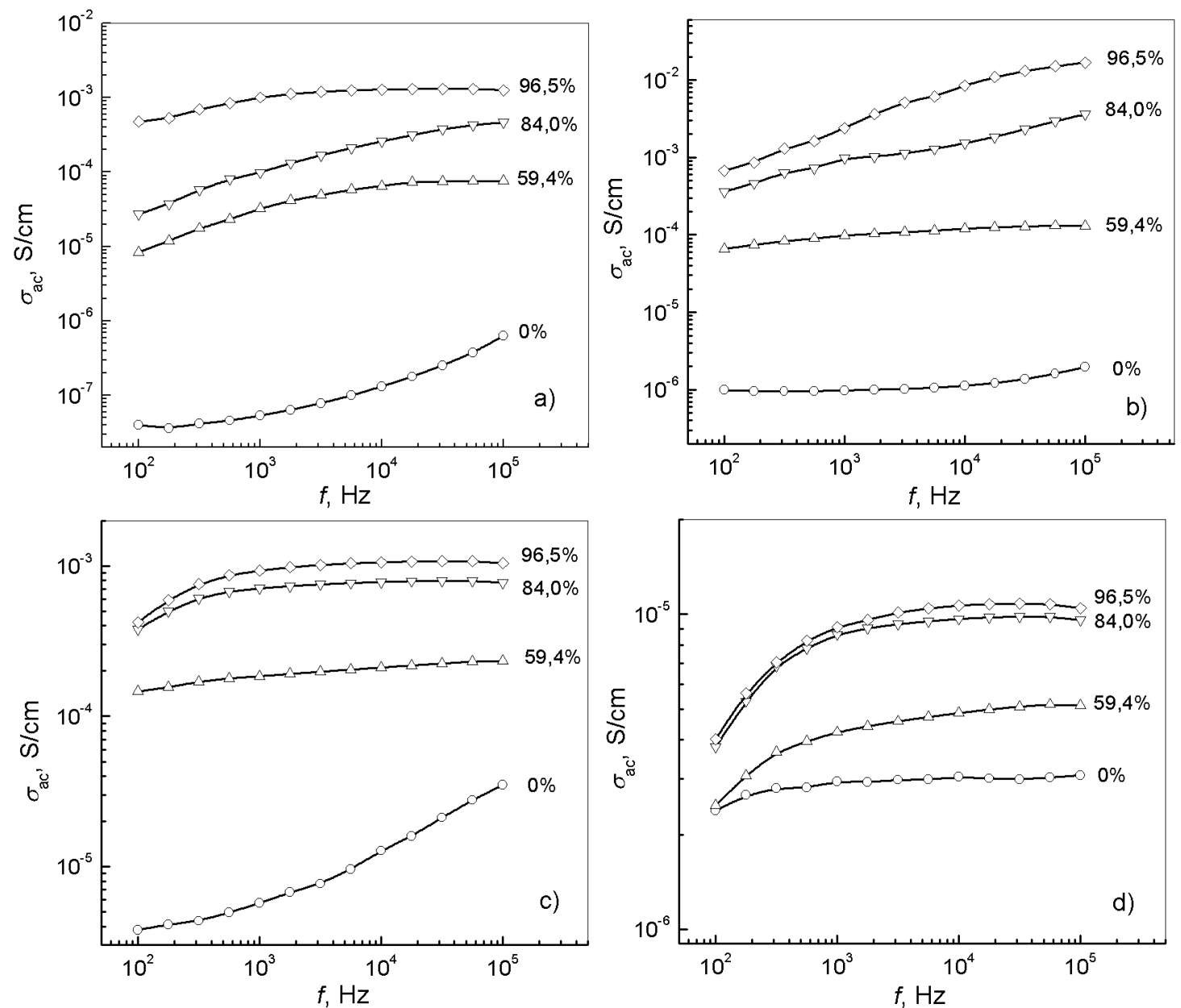

Fig. 2. Frequency dependences of alternating current conductivity on $R H$ at $293 \mathrm{~K}$ for capacitiveresistive sensors based on initial organic-inorganic matrix (a) and nanocomposites with content of CNT: $0.1 \%(b), 0.5 \%$ (c) and $1 \%(d)$.

To improve the sensory properties of the matrix composite, such as conductivity, linearity and speeds of recovery, CNT was additionally introduced to its composition (see experimental part) [1].

Fig. 2 shows the frequency dependences of conductivity with different $R H$ for experimental samples of sensory materials made from probed ion-conducting organicinorganic systems. It is shown that for all investigated systems there is a tendency to growth of conductivity with the increase of humidity level of the system. Such behavior of sensory materials is caused by the increase of amount of adsorbed moisture from the probed atmosphere with increase of its humidity, which contributes to dissociation of ionogenic group, performs the role of ion-conducting environment and promotes mobility of polyethyleneoxide component capable of ionic transfer [25]. For the initial neat organic-inorganic matrix at humidity of environment equal to $96.5 \%$, the value of conductivity is of the order of $10^{-3} \mathrm{~S} / \mathrm{cm}$. Conductivity at the maximal probed humidity grows by an order and makes $10^{-2} \mathrm{~S} / \mathrm{cm}$ when $0.1 \%$ CNT was introduced to the system. With the subsequent adding of nanotubes to the system in an amount of 0.5 and $1 \%$, conductivity at maximal humidity decreases to $10^{-3}$ and $10^{-5} \mathrm{~S} / \mathrm{cm}$, respectively.

Fig. 3 shows dependences of conductivity on $R H$ of the environment for the experimental samples of sensory materials. It was established that conductivity for the probed systems depends not only on humidity of environment but also on measuring frequency. For an initial organic-inorganic matrix, the increase of frequency from $100 \mathrm{~Hz}$ to $100 \mathrm{kHz}$ leads to the growth of conductivity approximately by a half of order in the whole range of humidity. The conductivity weakly depends on frequency when $0.1 \%$ CNT is introducted to the system. 

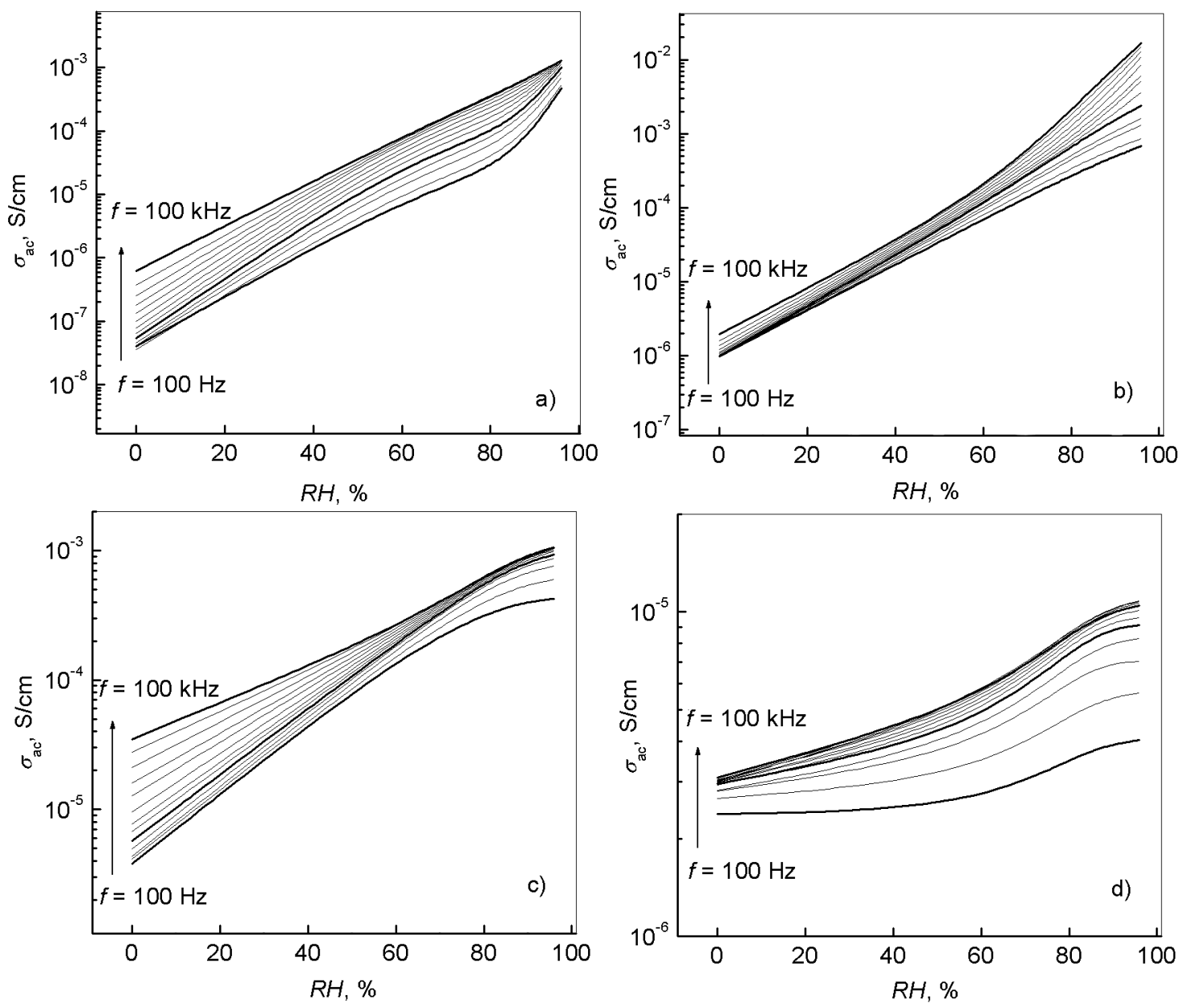

Fig. 3. Dependences of alternating current conductivity on $R H$ at the fixed values of frequencies for capacitive-resistive sensors based on initial organic-inorganic matrix (a) and nanocomposites with content of CNT: 0,1\%(b), 0,5\% (c) and $1 \%(d)$.

Such characteristics of this sensory material provide measuring of humidity values of environment with the use of practically any of the fixed frequencies in a range from 0.1 to $100 \mathrm{kHz}$. With growth of CNT content in the system, conductivity again begins to depend considerably on frequency, which results in worsening of sensory characteristics of the investigated materials.

In Fig. 4 the dependence of conductivity on $R H$ for the probed systems with different filling of CNT is presented. It is shown that for all of the probed systems the dependence $\sigma(R H)$ is linear in semilogarithmic coordinates, which enables the use of such materials as sensor devices for control of environment humidity. Slope of linear dependences $\sigma(R H)$ can come forward as characteristic of the sensor reacting speed on changes in the environment humidity. It is shown in Fig. 4 that the most rapid response is noted for the material containing
$0.1 \% \mathrm{CNT}$, and with the increase of relative humidity from 0 to $96.5 \%$ the conductivity grows more than by four orders. These results indicate very high sensitivity of sensors based on this material.

The nonlinear dependence of sensory characteristics with increase of CNT content in the system is related to the percolation processes. For the investigated materials, a percolation behavior is manifested in formation of "continuous" percolation clusters from nanotubes, which contact between themselves and cardinally change the system properties. According to the literature information, the percolation threshold (the nanotubes content at which takes place formation of a percolation cluster) is equal to $0.42 \%$ for the systems based on PEG-1000 and CNT [26]. Consequently, taking into account that the basic organic component of the probed systems are fragments of PEG1000 , at the CNT concentration in nanocomposite equal to $0.1 \%$ (which is less than 


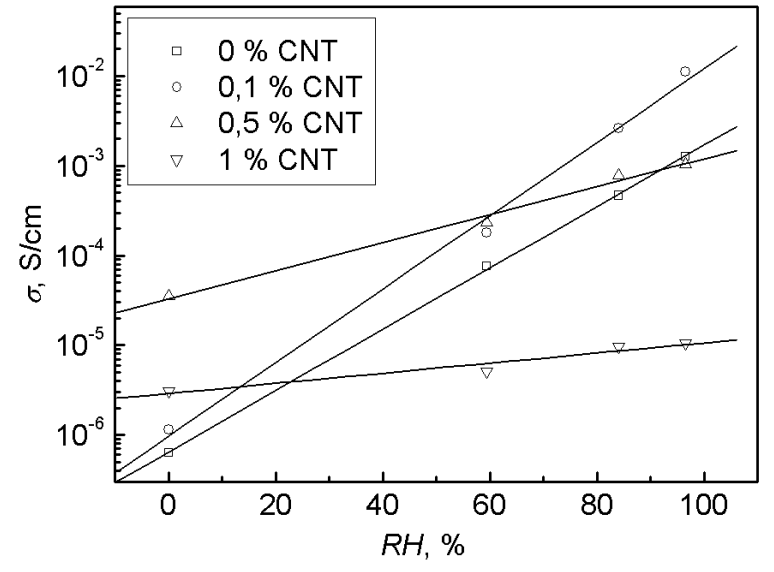

Fig. 4. Conductivity dependences on $R H$ for capacitive-resistive sensor based on initial organic-inorganic matrix and nanocomposites with different content of CNT at frequency of $100 \mathrm{kHz}$.

the percolation threshold), the nanotubes, probably, do not contact between themselves. Such system is characterized by the absence of electronic type of conductivity, which can considerably worsen sensory characteristics of this material. An increase in conductivity of this system is provided by some structure formation by carbon nanotubes in the matrix material. The specific transitional (interphase) layers are formed around nanotubes. For this system, transitional layers are the solvating layers of PEG, which appear on the surface of CNT. Such layers are characterized by higher conductivity in comparison to the polymer matrix [27]. The schematic model of structure of the nanofilled systems is presented at Fig. 5 .

The subsequent increase of CNT content in the system leads to the decrease of conductivity levels. This effect is explained by the reaching of percolation threshold by the system. At CNT content equal to 0.5 and $1 \%$, nanotubes contact between themselves through forming direct contacts or tunneling which results in growth of electronic conductivity contribution in general conductivity of the system. Another negative factor of greater content of nanotubes introducted to the system is considerable processes of aggregation, which take place because of powerful Van-der-Vaals forces operating between CNT [6,7].

The next stage of our work was studying the characteristics of long duration exploitation of capacitive-resistive sensors based on the developed materials. The essence of the research consisted in measuring the con-

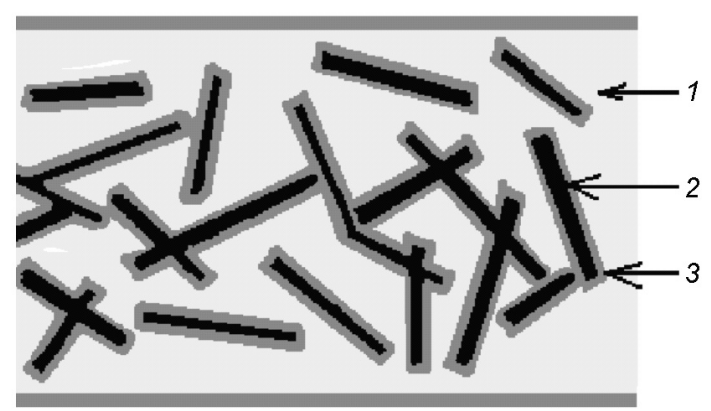

Fig. 5. Schematic image of structure model of organic-inorganic matrix filled with CNT. 1 - bulk phase of matrix, $2-\mathrm{CNT}$, 3 - a transitional layer between a matrix and CNT.

ductivity of sensory materials when they were moved from the medium with zero humidity to a medium corresponding to $96.5 \% R H$. The response time (time of achievement of a stable level of the recorded signal) when using the dry sensor based on initial organic-inorganic matrix was equal to $10-15 \mathrm{~min}$. The recovery time (at transferring from an environment where the level of humidity was $96.5 \%$ to the absolutely dry atmosphere) is equal to 3060 min. Introduction of CNT with a hydrophobic surface decreased the recovery time of materials to $10-15 \mathrm{~min}$.

\section{Conclusions}

The method of obtaining the organic-inorganic ion-conducting composition using sol-gel method was developed and the modification of it with CNT was performed. The synthesized materials are marked by high adhesion to the surfaces of metallic electrodes and dielectric lining of capacitive-resistive sensors, and by high sensory characteristics. In particular, the levels of its ionic conductivity depending on CNT content and environment humidity are $10^{-7}-10^{-3} \mathrm{~S} / \mathrm{cm}$.

Sensory characteristics of the developed materials in composition of experimental samples of capacitive-resistive gas sensors were investigated. It was established that conductivity of the probed systems depends on the environment humidity, measuring frequency and CNT content in the system. For the system filled with $0.1 \%$ CNT, the measured conductivity weakly depends on frequency, allowing measurements of the environment humidity values with the use of practically any of the fixed frequencies in the range from 0.1 to $100 \mathrm{kHz}$. It has 
been shown that sensors containing $0.1 \%$ CNT, demonstrate the highest speed of reacting and sensitiveness. It has been found that in these systems the processes of CNT percolation, which considerably affect the sensory characteristics of such materials, play an important role. The response time and the recovery time of sensors based on organic-inorganic matrix considerably decrease with CNT introduction to the system.

Thus, the most optimum characteristics for all parameters under investigation were shown by a material based on organic-inorganic matrix filled with $0.1 \%$ CNT. This material is very promising for creation of capacitance-resistance gas sensors for monitoring of the environment humidity level.

\section{References}

1. Y.Wang, J.T.W.Yeow, J. Sens., 1 (2009).

2. W.Bauhofer, J.Z.Kovacs, Compos.Sci.Technol., 69, 1486 (2009).

3. E.A.Lysenkov, Y.V.Yakovlev, V.V.Klepko, Ukr. Phys., J, 58, 378 (2013).

4. M.Rahmat, P.Hubert, Compos.Sci.Technol., 72, 72 (2011).

5. T.Kashiwagi, E.Grulke, J.Hilding et al., Polymer, 45, 4227 (2004).

6. L.N.Lisetski, A.M.Chepikov, S.S.Minenko et al., Functional. Materials, 18, 143 (2011).

7. L.N.Lisetski, N.I.Lebovka, S.V.Naydenov et al., J.Mol.Liq., 164, 143 (2011).

8. J.N.Coleman, Adv.Funct.Mater., 19, 3680 (2009).

9. E.A.Lysenkov, N.I.Lebovka, Y.V.Yakovlev et al., Compos. Sci.Technol., 72, 1191 (2012).
10. H.-Z.Chen, R.Bai, L.Cao et al., Res. Chem.Intermediates, 34, 115 (2008).

11. Q.Y.Tang, Y.C.Chan, K.L.Zhang, Sens.Actuators $B, 152,96$ (2011).

12. Y.Li, L.J.Hong, Y.S.Chen et al., Sens.Actuators $B, 123,554$ (2007).

13. H.H.Yu, T.Cao, L.D.Zhou et al., Sens.Actuators $B, 119,512$ (2006).

14. A.Matsuda, Y.Nono, K.Tadanaga, Solid State Ionics, 162-163, 253 (2003).

15. J.Zeng, A.Almadidy, J.Watterson, Sens.Actuators, 90, 68 (2003).

16. A.Trinchi, Y.X.Li, W.Wlodarski, Sens.Actuators, 95, 145 (2003).

17. F.Qiu, Q.Zhu, X.Yang, Sens.Actuators, 93, 237 (2003).

18. A.Bearzotti, J.M.Bertolo, P.Innocenzi, Sens. Actuators, 95, 107 (2003).

19. V.V.Shilov, O.A.Shilova, L.N.Efimova et al., Perspect. Mater., b, 31, 31 (2003).

20. O.A.Shilova, S.V.Hashkovsky, E.V.Tarasyuk, J.Sol-Gel Sci.\&Technol., 25, 1131 (2003).

21. A.V.Stryutskiy, E.A.Lysenkov, A.R.Zolotarev et al., Ukr.Khim.J., 77, 116 (2011).

22. A.V.Melezhyk, Yu.I.Sementsov, V.V.Yanchenko, Prikl. Khim., 78, 938 (2005).

23. A.Kyritsis, P.Pissis, J.Grammatikakis, $J$. Polymer Sci.:Part B: Polymer Phys., 33, 1737 (1995).

24. V.S.Kolosnitsyn, G.P.Dukhanin, S.A.Dumler et al., Russ.J.of Appl.Chem., 78, 1 (2005).

25. V.V.Shevchenko, A.V.Stryutskii, N.S.Klimenko, Theor. Exp.Chem., 47, 67 (2011).

26. E.A.Lysenkov, V.V.Klepko, V.M.Golovanets et al., Ukr.J.Phys., 59, 906 (2014).

27. E.A.Lysenkov, Yu.P.Gomza, V.V.Davidenko et al., Phys. Cond.Macromol.Systems, 14, 15 (2010). 